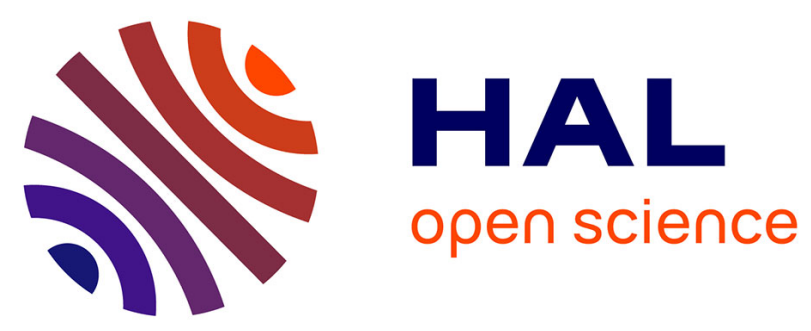

\title{
From Antarctica to the subtropics: contrasted geographical concentrations of selenium, mercury, and persistent organic pollutants in skua chicks (Catharacta spp.)
}

Alice Carravieri, Yves Cherel, Maud Brault-Favrou, Carine Churlaud, Laurent

Peluhet, Pierre Labadie, Hélène Budzinski, Olivier Chastel, Paco Bustamante

\section{To cite this version:}

Alice Carravieri, Yves Cherel, Maud Brault-Favrou, Carine Churlaud, Laurent Peluhet, et al.. From Antarctica to the subtropics: contrasted geographical concentrations of selenium, mercury, and persistent organic pollutants in skua chicks (Catharacta spp.). Environmental Pollution, 2017, 228, pp.464-473. 10.1016/j.envpol.2017.05.053 . hal-01683224

\section{HAL Id: hal-01683224 https://hal.science/hal-01683224}

Submitted on 12 Jan 2018

HAL is a multi-disciplinary open access archive for the deposit and dissemination of scientific research documents, whether they are published or not. The documents may come from teaching and research institutions in France or abroad, or from public or private research centers.
L'archive ouverte pluridisciplinaire HAL, est destinée au dépôt et à la diffusion de documents scientifiques de niveau recherche, publiés ou non, émanant des établissements d'enseignement et de recherche français ou étrangers, des laboratoires publics ou privés. 


\section{From Antarctica to the subtropics: contrasted geographical}

concentrations of selenium, mercury, and persistent organic pollutants in skua chicks (Catharacta spp.)

Alice Carravieri $^{\mathrm{a} *}$, Yves Cherel ${ }^{\mathrm{a}}$, Maud Brault-Favrou ${ }^{\mathrm{b}}$, Carine Churlaud $^{\mathrm{b}}$, Laurent Peluhet ${ }^{\mathrm{c}}$, Pierre Labadie $^{\mathrm{c}}$, Hélène Budzinski ${ }^{\mathrm{c}}$, Olivier Chastel ${ }^{\mathrm{a}}$, Paco Bustamante ${ }^{\mathrm{b}}$

${ }^{a}$ Centre d'Etudes Biologiques de Chizé, UMR 7372 CNRS-Université de La Rochelle, 79360 Villiers-en-Bois,

France

${ }^{\mathrm{b}}$ Littoral Environnement et Sociétés (LIENSS), UMR 7266 CNRS-Université de la Rochelle, 2 rue Olympe de Gouges, 17000 La Rochelle, France

${ }^{\circ}$ CNRS, UMR 5805 EPOC (LPTC Research group), Université de Bordeaux, 351 Cours de la Libération F 33405 Talence Cedex France

*Corresponding author: A. Carravieri.

E-mail address: alice.carravieri@gmail.com

Full postal address: Centre d'Etudes Biologiques de Chizé, UMR 7372 CNRSUniversité de La Rochelle, 405 Route de La Canauderie, 79360 Villiers-en-Bois, France 
Abstract : Seabirds integrate bioaccumulative contaminants via food intake and have revealed geographical trends of contamination in a variety of ecosystems. Pre-fledging seabird chicks are particularly interesting as bioindicators of chemical contamination, because concentrations in their tissues reflect primarily dietary sources from the local environment. Here we measured 14 trace elements and 18 persistent organic pollutants (POPs) in blood of chicks of skuas that breed in four sites encompassing a large latitudinal range within the southern Indian Ocean, from Antarctica (Adélie Land, south polar skua Catharacta maccormicki), through subantarctic areas (Crozet and Kerguelen Islands, brown skua C. lonnbergi), to the subtropics (Amsterdam Island, C. lonnbergi $)$. Stables isotopes of carbon $\left(\delta^{13} \mathrm{C}\right.$, feeding habitat $)$ and nitrogen $\left(\delta^{15} \mathrm{~N}\right.$, trophic position) were also measured to control for the influence of feeding habits on contaminant burdens. Concentrations of mercury $(\mathrm{Hg})$ and selenium $(\mathrm{Se})$ were very high at all the four sites, with Amsterdam birds having the highest concentrations ever reported in chicks worldwide ( $4.0 \pm 0.8$ and $646 \pm 123 \mu \mathrm{g} \mathrm{g}^{-1}$ dry weight, respectively). Blood $\mathrm{Hg}$ concentrations showed a clear latitudinal pattern, increasing from chicks in Antarctica to chicks in the subantarctic and subtropical islands. Interestingly, blood Se concentrations showed similar between-population differences to $\mathrm{Hg}$, suggesting its involvement in protective mechanisms against Hg toxicity. Chicks' POPs pattern was largely dominated by organochlorine pesticides, in particular DDT metabolites and hexachlorobenzene (HCB). Skua chicks from subantarctic islands presented high concentrations and diversity of POPs. By contrast, chicks from the Antarctic site overall had the lowest concentrations and diversity of both metallic and organic contaminants, with the exception of HCB and arsenic. Skua populations from these sites, being naturally exposed to different quantities of contaminants, are potentially good models for testing toxic effects in developing chicks in the wild.

Key words: Bioaccumulation, Blood, Chick, HCB, Southern Ocean, Stable Isotopes. 


\section{Introduction}

Anthropogenic activities have profoundly modified physical and chemical processes at the Earth's surface, with pervasive environmental pollution being one of the major consequences. Global fluxes of trace elements such as mercury $(\mathrm{Hg})$, lead $(\mathrm{Pb})$ and arsenic $(\mathrm{As})$ are exceedingly influenced by human activities (mining, fossil fuel combustion, construction; Rauch and Pacyna, 2009; Sen and Peucker-Ehrenbrink, 2012). In addition, a multitude of synthetic chemicals have been released into the environment, with some of them, such as the highly toxic persistent organic pollutants (POPs, www.pops.int) being still widespread and threatening ecosystems worldwide. The ocean plays a critical role in the biogeochemical cycle of trace elements (Coale et al., 1996; SCOR Group, 2007) and in the global dynamics of POPs (Dachs et al., 2002; Nizzetto et al., 2010). Yet there is still a significant dearth of knowledge on the distributions of trace elements and POPs in the World Ocean. Seabirds can be effectively used as bioindicators of contamination in vast oceanic regions, because they integrate the contamination of their food webs through bioaccumulation and biomagnification mechanisms over large spatial scales, and breed on land in colonies where they are easily accessible (Elliott and Elliott, 2013). Despite their interest as bioindicators, still little is known on seabird contaminant exposure, in particular for trace elements such as copper $(\mathrm{Cu})$, iron $(\mathrm{Fe})$ or selenium (Se) (but see e.g. Anderson et al., 2010; Borgå et al., 2006; Fromant et al., 2016). These trace elements are essential for biological processes within a narrow window of concentrations, but can lead to deleterious effects outside of it (deficiency below and toxicity above), and have the potential to interact with other metallic and organic contaminant uptake, storage, and toxic effects (Walker et al., 2012). In particular, Se has a well-known protecting role against $\mathrm{Hg}$ toxicity (Khan and Wang, 2009), yet only a few studies have quantified $\mathrm{Hg}-\mathrm{Se}$ coexposure and interaction in seabirds (but see e.g. Carvalho et al., 2013; Cipro et al., 2014; Gonzalez-Solís et al., 2002). Furthermore, large-scale trace element and POPs distributions in 
the World Ocean are poorly known, especially in the Southern Hemisphere (SCOR Group, 2007), and seabirds could help in understanding potential geographical differences in their bioavailability. Seabird species with large distributions are particularly useful as bioindicators, because the comparison of distinct populations allow inferring geographical differences in contamination of food webs with a limited phylogenetic bias (Brasso et al., 2015; Carravieri et al., 2016; Roscales et al., 2016).

Food is the main contaminant exposure route in seabirds, thus trophic ecology must be taken into account when evaluating geographical and temporal trends of contamination (Brasso et al., 2015; Braune et al., 2014). By coupling the quantification of environmental contaminants and trophic tracers such as the stable isotopes of carbon and nitrogen $\left(\delta^{13} \mathrm{C}\right.$ and $\delta^{15} \mathrm{~N}$ as proxies of foraging habitats and diets, respectively), recent studies on seabirds have highlighted geographical differences in environmental contaminant transfer to predators in the Southern Ocean. Namely, feather $\mathrm{Hg}$ concentrations of penguin and albatross species from distinct sites in the Southern Hemisphere indicated potential "hot-spots" of Hg bioavailability, such as Staten Island in the southern Atlantic Ocean (Brasso et al., 2015) or the subtropical waters of the Indian Ocean (Bustamante et al., 2016). In addition, POP exposure of Southern Ocean top predators had different latitudinal patterns in the Southern Atlantic (increasing northward, Roscales et al., 2016) and Indian Oceans (increasing southward, Carravieri et al., 2014). Most of these studies have been conducted in adult seabirds (but see Blévin et al., 2013; Colabuono et al., 2016), where the interpretation of tissue contaminant concentrations may be blurred by confounding factors such as exposure over different temporal and spatial scales (during the breeding vs wintering season) (Bourgeon et al., 2013; Fort et al., 2014), thus limiting our capacity to effectively infer geographical differences in exposure.

The present study focuses on two sibling seabird species from the southern Indian Ocean: the south polar skua Catharacta maccormicki and the brown skua C. lonnbergi. Hg, 13 other trace 
elements, and 18 persistent organic pollutants (POPs, including organochlorine pesticides, OCPs, and polychlorinated biphenyls, PCBs) were measured in blood of pre-fledging chicks during the same breeding season from four sites that encompass a large latitudinal range: from Antarctica (Adélie Land, Catharacta maccormicki), through subantarctic areas (Crozet and Kerguelen Islands, C. lonnbergi), to the subtropics (Amsterdam Island, C. lonnbergi). Contaminant concentrations in pre-fledging chicks are more easily related to dietary sources than those of adults and represent primarily the local environment (Burger and Gochfeld, 2004). This offers an exceptional opportunity to compare contaminant exposure in geographically distant, but phylogenetically and ecologically closely-related seabird populations. The short time window of sampling also minimises the influence of a potential temporal variation in contaminant concentrations in the skuas' food webs. This work has two main objectives: first, to describe the concentrations of several metallic and organic contaminants in blood of skua chicks, compare it to other seabirds from similar environments, and evaluate potential toxicity; and second to infer potential geographical patterns of exposure within the southern Indian Ocean.

\section{Material and methods}

\subsection{Study sites and sampling procedure}

Fieldwork was conducted at four sites of the Terres Australes et Antarctiques Françaises that are representative of different water masses of the southern Indian Ocean, namely Adélie land $\left(66^{\circ} 40^{\prime} \mathrm{S}, \quad 140^{\circ} 01^{\prime} \mathrm{E}\right)$ in high-Antarctica, Kerguelen $\left(49^{\circ} 21^{\prime} \mathrm{S}, 7^{\circ} 18^{\prime} \mathrm{E}\right)$ and Crozet Archipelagos $\left(46^{\circ} 26^{\prime} \mathrm{S}, 51^{\circ} 45^{\prime} \mathrm{E}\right)$ in the subantarctic zone sensus lato (between the Polar Front and the Subtropical Front), and Amsterdam Island (37 $\left.50^{\prime} \mathrm{S}, 77^{\circ} 31^{\prime} \mathrm{E}\right)$ in the subtropics (north the Subtropical Front). Two sibling species of skuas breed at these sites, the brown skua at Kerguelen, Crozet and Amsterdam Islands, and the south polar skua in Adélie Land. One single 
well-feathered skua chick per nest was captured by hand before fledging during the 2011-2012 breeding season at all sites ( $\mathrm{N}=41$ across all sites). Blood was sampled from the wing vein with a 2-mL heparinized syringe. Whole blood was centrifuged less than 2 hours after sampling, and blood cells and plasma were stored at $-20{ }^{\circ} \mathrm{C}$ until laboratory analyses in France.

\subsection{Diet}

Skuas have a high plasticity in feeding methods, being able to (i) scavenge on seabird and marine mammal carcasses, (ii) actively prey upon eggs and seabirds on land, (iii) fish at sea, and (iii) kleptoparatize other seabirds (Furness, 1987; Olsen and Larsson, 1997). During the chick rearing period, parents remain largely on land or coastal habitats to seek food for their offspring, usually exploiting other seabirds' colonies in the vicinity of the nests. At our field station in Adélie Land, south polar skua chicks are mainly fed eggs and carcasses of Adélie penguins Pygoscelis adeliae (Centre d'Etudes Biologique de Chizé, CEBC, unpublished data). In the Kerguelen Archipelago, brown skua chicks were sampled at Mayès Island, where skuas rely almost exclusively on small burrowing petrels that breed there, in particular the blue petrel, Halobaena caerulea, but also the thin-billed prion, Pachyptila belcheri (Mougeot et al., 1998). Skua chick diet at Pointe Basse, Possession Island, Crozet Archipelago, comprises eggs and carcasses of crested penguins (Eudyptes spp.), but also introduced black rats Rattus rattus (Stahl and Mougin, 1986). Finally, at Amsterdam Island, skua diet is poorly known, but field observations indicate that chicks are fed eggs and carcasses of other seabirds, but also with scavenged subantarctic fur seals, Arctocephalus tropicalis and introduced brown rats Rattus norvegicus.

\subsection{Trace element, POP and stable isotope analyses}

Blood is very useful for contaminant evaluation in seabirds: circulating levels are representative of dietary exposure and are in equilibrium with internal tissue concentrations (Eagles-Smith et 
al., 2009; Henriksen et al., 1998; Szumiło et al., 2013). Trace elements were measured at the laboratory LIENSs, La Rochelle, France, from lyophilized red blood cells, where they preferentially partition (Coeurdassier et al., 2012; Tavares et al., 2013). Total Hg was quantified with an Altec AMA 254 spectrophotometer on aliquots of 5-10 mg dry weight (dw) as described in Bustamante et al. (2006). All analyses were repeated in duplicate-triplicate until having a relative standard deviation $(\mathrm{SD})<10 \%$ for each individual. Accuracy was checked using a certified reference material (CRM, TORT-2 Lobster Hepatopancreas, NRC, Canada; certified Hg concentration: $0.27 \pm 0.06 \mu \mathrm{g} \mathrm{g}^{-1} \mathrm{dw}$ ). Our measured values were $0.27 \pm 0.01 \mu \mathrm{g} \mathrm{g}^{-1} \mathrm{dw}, \mathrm{N}$ $=44$. Mass of the CRM was adjusted to represent an amount of $\mathrm{Hg}$ similar to that in blood samples. Blanks were analysed at the beginning of each set of samples and the limit of detection (LOD) was $0.005 \mu \mathrm{g} \mathrm{g}^{-1} \mathrm{dw}$.

Arsenic (As), chromium $(\mathrm{Cr})$, copper $(\mathrm{Cu})$, iron $(\mathrm{Fe})$, manganese $(\mathrm{Mn})$, nickel $(\mathrm{Ni})$, selenium (Se) and zinc (Zn) were analysed using a Varian Vista-Pro ICP-OES and silver (Ag), cadmium $(\mathrm{Cd})$, cobalt $(\mathrm{Co})$, lead $(\mathrm{Pb})$ and vanadium $(\mathrm{V})$ using a Thermo Fisher Scientific X Series 2 ICPMS, following Kojadinovic et al. (2011) (aliquots mass: 20-200 mg dw). Measurement quality was assessed by CRM (TORT-2 Lobster Hepatopancreas and DOLT-4 Dogfish Liver, both NRC, Canada), with elements recovery ranging from $70 \%$ to $113 \%$. Blanks were included in each analytical batch. The LODs $\left(\mu \mathrm{g} \mathrm{g}^{-1} \mathrm{dw}\right)$ were $0.015(\mathrm{Cd}), 0.017(\mathrm{Ag}), 0.02(\mathrm{Cr}, \mathrm{Co}, \mathrm{Pb})$, $0.03(\mathrm{Ni}), 0.08(\mathrm{Mn}), 0.1(\mathrm{Cu}, \mathrm{Se}), 0.2(\mathrm{As}), 0.3(\mathrm{~V})$ and $3.3(\mathrm{Fe}$ and $\mathrm{Zn})$.

POPs were measured at the laboratory EPOC-LPTC, Bordeaux, France, from plasma (300 $\mu 1$ aliquots), where they preferentially partition (Keller et al., 2004; Matthews et al., 1984). The targeted compounds were seven PCBs (CB-28, -52, -101, -118, -138, -153 and -180) and 11 OCPs (HCB, $\gamma$-HCH, Heptachlor, 2,4'-DDE, 4,4'-DDE, cis-chlordane, trans-nonachlor, 4,4'DDD, 2,4'-DDT, 4,4'-DDT, Mirex). The targeted CB-28 co-eluted with CB-50 in all samples and is thus reported as CB-28/50 in the text. Internal standards (CB-30, -103, -155, -198 and 
p,p'-DDT-d8, 1 ng each) were added to each sample. Standards were provided by either Dr Ehrenstorfer GmbH or Cambridge Isotope Laboratory (via Cluzeau Info Labo, Sainte-Foy-LaGrande, France). Sample extraction, purification and concentration followed the procedure described in Carravieri et al. (2014). Replicate procedural blanks were analysed for each series of samples and, when applicable, POP concentrations were blank corrected. Final extracts were analysed by gas chromatography coupled with electron capture detection (GC-ECD) as described in Tapie et al. (2011). Recovery rates, as determined on spiked chicken plasma, were in the range $54 \%-118 \%$. The limits of quantification (LOQ, $\mathrm{ng} \mathrm{g}^{-1}$ wet weight, ww) were 0.1 (CB-180), 0.3 (CB-28/50), 0.6 (CB-153), 0.7 (CB-138), 1.1 (CB-101), 1.4 (CB-118), 1.8 (CB52) for PCBs, and 0.05 (Heptachlor and trans-nonachlor), 0.06 (HCB and 4,4'-DDE), 0.09 (cischlordane), 0.1 (4,4'-DDT and Mirex), 0.2 (2,4'-DDE and $\gamma$-HCH), 0.3 (2,4'-DDT), and 0.4 (4,4'-DDD) for organochlorine pesticides.

Carbon $\left(\delta^{13} \mathrm{C}\right)$ and nitrogen $\left(\delta^{15} \mathrm{~N}\right)$ stable isotope ratios were determined at the laboratory LIENSs in red blood cells with a continuous flow mass spectrometer (Thermo Scientific Delta V Advantage) coupled to an elemental analyser (Thermo Scientific Flash EA 1112) (aliquots mass: $\sim 0.3 \mathrm{mg}$ ). Results are in $\delta$ notation relative to Vienna PeeDee Belemnite and atmospheric $\mathrm{N}_{2}$ for $\delta^{13} \mathrm{C}$ and $\delta^{15} \mathrm{~N}$, respectively. Measurement errors were $<0.15 \%$.

Results are given as mean \pm SD in $\mu \mathrm{g} \mathrm{g}^{-1} \mathrm{dw}$ for trace elements, in $\mathrm{ng} \mathrm{g}^{-1} \mathrm{ww}$ for POPs, and in \%o for stable isotope values. "Blood" within the text refers either to blood cells for trace element and stable isotope values, or plasma for POP values.

\subsection{Statistical analysis}

Statistical analyses were carried out using R 3.2.3 (R Core Team 2015). Only trace elements and POPs with concentrations above the LOQ in at least $70 \%$ of individuals were included in statistical analyses. Concentrations below the LOQ were substituted using random values between 0 and the LOQ. First, a principal component analysis (PCA) was carried out on 
selected, log-transformed and scaled trace elements and POPs in order to highlight co-variance and to identify the contaminants reflecting most of the total variance in the data. Blood $\delta^{13} \mathrm{C}$ values were included in the PCA as a supplementary (passive) variable (Anderson et al., 2010; Borgå et al., 2006) in order to explore contaminant relationships with feeding habitat. Second, univariate analyses (linear or generalised linear models, GLM) were used to test the effect of site and feeding ecology (inferred from stable isotopes) on trace elements and POPs with high factor loadings in the PCA (compounds with factor loadings $\geq 0.50$ on PC1 or PC2, Table S1 in the Supplementary Information, SI)). Forward selection using the Akaike's Information Criterion corrected for small sample sizes (AICc) was applied, and the effect of variables affecting contaminant burdens was inferred through Akaike's weights (Burnham and Anderson, 2002) and explained variance. Post-hoc Tukey's honestly significant difference (HSD) tests were applied on the selected best model to evaluate site differences in contaminant concentrations. The $\delta^{15} \mathrm{~N}$ variable was not included in multifactorial analyses given the known latitudinal ${ }^{15} \mathrm{~N}$ baseline enrichment north of the Subtropical Front (Altabet and Francois, 1994; Cherel and Hobson, 2007; Jaeger et al., 2010), which prevents comparing directly blood $\delta^{15} \mathrm{~N}$ values as a proxy of trophic positions of individuals over the large latitudinal range considered here. The effect of species on contaminant concentrations could not be tested since the south polar skua breeds only at one site, thus the species effect is confounded by the site effect. For all analyses, model specification and validation were based on residual analysis (Zuur et al., 2009).

\section{Results}

\subsection{Trace element, POP and stable isotope values}

Among the 14 targeted trace elements, the essential $\mathrm{Cu}, \mathrm{Fe}, \mathrm{Se}$ and $\mathrm{Zn}$ and the non-essential $\mathrm{Hg}$ were quantifiable in all individuals. The essential $\mathrm{Co}$ and $\mathrm{V}$ and the non-essential $\mathrm{Ag}$ and $\mathrm{Cd}$ 
were not detected in any individual, while $\mathrm{Cr}, \mathrm{Mn}, \mathrm{Ni}$ and $\mathrm{Pb}$ were detected in low concentrations in a few of them (Table S2 in the SI). Interestingly, As was quantifiable in all skua chicks from Adélie Land $\left(1.04 \pm 0.98 \mu \mathrm{g} \mathrm{g}^{-1} \mathrm{dw}\right)$ and Amsterdam Island $(0.52 \pm 0.21 \mu \mathrm{g}$ $\mathrm{g}^{-1} \mathrm{dw}$ ), but not at the subantarctic sites (Table S2 in the SI). PCA analysis indicated that trace elements contributing most to the total variation in the dataset were $\mathrm{Cu}$ (overall in the range: 0.54-1.43 $\mu \mathrm{g} \mathrm{g}^{-1} \mathrm{dw}$, Table S2 in the SI), $\mathrm{Hg}\left(0.36-5.80 \mu \mathrm{g} \mathrm{g}^{-1} \mathrm{dw}\right)$ and Se $\left.19-863 \mu \mathrm{g} \mathrm{g}^{-1} \mathrm{dw}\right)$, while Fe (2007-2353 $\left.\mu \mathrm{g} \mathrm{g}^{-1} \mathrm{dw}\right)$ and $\mathrm{Zn}\left(21-32 \mu \mathrm{g} \mathrm{g}^{-1} \mathrm{dw}\right)$ varied less among individuals (factor loadings $<50 \%$, Table S1 in the SI, see also section 3.2.). Se:Hg molar ratios were high, reaching $636 \pm 153$ in the Kerguelen population (Table 1).

Among the 18 targeted POPs, several compounds were not quantifiable in most skua chicks, in particular PCBs, with congener CB-180 only having quantifiable concentrations in some individuals at all sites (overall in the range 0.1-0.4 $\mu \mathrm{g} \mathrm{g}^{-1} \mathrm{dw}$, Table S3 in the SI). Hence, OCPs largely dominated the skua chicks' POP pattern (86-95\% of the $\sum 18 \mathrm{POPs}$ on average, Table S4 in the SI), but several compounds were under the LOQ, notably $\gamma-\mathrm{HCH}$, cis-chlordane and some DDT metabolites (Table S3 in the SI). The most abundant POP was HCB (>LOQ in 100\% individuals), followed by 4,4'-DDE (>LOQ in $85 \%$ individuals). HCB and 4,4'-DDE also had the highest mean concentrations of the dataset, with skua chicks from Kerguelen Islands having the highest burdens for both compounds (Table 1).

Blood $\delta^{13} \mathrm{C}$ and $\delta^{15} \mathrm{~N}$ values varied widely among skua chick populations (ANOVA, F3,37 = 730 and 192, respectively, both $\mathrm{p}<0.0001$ ). The populations occupied different isotopic niches, with only $\delta^{15} \mathrm{~N}$ values being similar in skua chicks from Kerguelen and Crozet Islands (Table $1)$. 


\subsection{Inter-contaminant patterns}

Initial PCA analyses including $\mathrm{Cu}, \mathrm{Fe}, \mathrm{Hg}, \mathrm{Se}, \mathrm{Zn}, \mathrm{HCB}$ and 4,4'-DDE (all with factors loading on $\mathrm{PC} 1$ or $\mathrm{PC} 2>50 \%$, Table $\mathrm{S} 1$ in the $\mathrm{SI}$ ) revealed associations between $\mathrm{Hg}$ and $\mathrm{Se}$, and between $\mathrm{Cu}$ and $\mathrm{Fe}$, while the two POPs were not strongly associated with each other (Fig. 1). Univariate analyses strongly confirmed the direct correlation between $\mathrm{Hg}$ and $\mathrm{Se}(\rho=0.89, \mathrm{p}<$ 0.0001). Overall $\mathrm{Hg}$, Se and 4,4'-DDE contributed most to PC1, while Cu and HCB contributed strongly to PC2 (Table S1 in the SI). The four skua populations were clearly separated in the ordination space (Fig. 1). In particular, the pattern of skua chicks from Amsterdam Island differed from that of the other populations by elevated $\mathrm{Hg}$ and essential element concentrations and low HCB values (Fig. 1). Amsterdam skua chick values also governed the distribution of $\delta^{13} \mathrm{C}$ values in the ordination space, indicating associations with $\mathrm{Hg}$, Se and $\mathrm{Zn}$ (Fig. 1).

\subsection{Geographical patterns of contaminant concentrations}

Multifactorial analyses showed that site alone explained most of the total variation in blood $\mathrm{Cu}$, $\mathrm{Hg}$, Se and HCB concentrations among the four skua populations (81-91\%, Table 2). In addition, $\delta^{13} \mathrm{C}$ values contributed significantly to explaining variation in the contamination, in particular for $\mathrm{Hg}$ and $\mathrm{HCB}$ (Table 2). On the other hand, site and $\delta^{13} \mathrm{C}$ values were related to 4,4'-DDE contamination but the best ranked model explained only $45 \%$ of the total variation in the data (Table 2). Hg concentrations were lowest in Adélie Land skua chicks and increased northward, being highest in Amsterdam skua chicks (Fig. 2). The same was true for Se concentrations (Fig. 2), except that Kerguelen skua chicks had surprisingly high $\mathrm{Se}$ concentrations when compared to their $\mathrm{Hg}$ burden, which resulted in very high $\mathrm{Se}: \mathrm{Hg}$ molar ratios (Table 1). Amsterdam skua chicks also had the highest blood $\mathrm{Cu}$ concentrations, but no 
clear latitudinal pattern was apparent (Table 1). Skua chicks from Kerguelen had the highest concentrations and abundance of several POPs, including HCB, 4,4'-DDE and Mirex (Table 1 and S3). On the other hand, the relative contribution of HCB to the $\sum 18 \mathrm{POPs}$ showed a reversed latitudinal pattern when compared to $\mathrm{Hg}$, Se and 4,4'-DDE, with HCB being dominant in Adélie Land skua chicks, and then being less represented further north, with Amsterdam skua chicks having the lowest HCB contribution (Fig. 2).

\section{Discussion}

This study is the first comprehensive report of blood concentrations of metallic and organic contaminants in multiple populations of skuas breeding in the Southern Hemisphere. Skua chicks from this large latitudinal range and during the same breeding year showed remarkable differences in the extent to which they accumulated trace elements and POPs, with no single population having the highest concentrations of all contaminants. Nevertheless, skua chicks from Amsterdam and Kerguelen Islands stood out in terms of quantity and diversity of compounds. In particular, and to the best of our knowledge, blood concentrations of $\mathrm{Hg}$ and $\mathrm{Se}$ in Amsterdam individuals were the highest ever reported in wild bird chicks in environments free of direct anthropogenic inputs of contaminants.

\subsection{Contaminant patterns and toxicological significance}

\subsection{1. $\mathrm{Hg}$ and Se and their interaction}

Few studies have reported trace elements concentrations in blood of birds in general and in seabird chicks in particular, making comparisons difficult. Brown skua chicks at all sites had higher blood Hg concentrations than wandering albatross Diomedea exulans chicks from South Georgia (southern Atlantic Ocean, $0.84 \mu \mathrm{g} \mathrm{g} \mathrm{g}^{-1} \mathrm{dw}$, Tavares et al., 2013). This result is remarkable since the wandering albatross is one of the birds with the highest $\mathrm{Hg}$ burdens 
worldwide (Carravieri et al., 2014; Tavares et al., 2013). Such elevated concentrations are consistent with both brown skuas and wandering albatrosses feeding at high trophic levels and being thus exposed to high quantities of $\mathrm{Hg}$ through its biomagnification in food webs (Walker et al., 2012). While there are no published data on $\mathrm{Hg}$ in blood of seabird chicks from other subtropical, subantarctic or Antarctic sites, chick blood $\mathrm{Hg}$ concentrations in brown skuas were higher than those of the phylogenetically and ecologically close great skua Catharacta skua from the Northern Hemisphere (Bearhop et al., 2000). Blood Hg burdens in south polar skua chicks were lower than those of brown skuas, and comparable to those of wandering albatross and great skua chicks (Bearhop et al., 2000; Tavares et al., 2013). Other seabird chicks worldwide usually have blood $\mathrm{Hg}$ concentrations $<1 \mu \mathrm{g} \mathrm{g}^{-1} \mathrm{dw}$ (Bond and Diamond, 2009; Burger and Gochfeld, 1997; Fevold et al., 2003; Hipfner et al., 2011; Kahle and Becker,1999; Sebastiano et al., 2016, 2017), except black-footed albatrosses Phoebastria nigripes (mean 0.78 $\mu \mathrm{g} \mathrm{g}^{-1} \mathrm{ww}$, about $3.1 \mu \mathrm{g} \mathrm{g}^{-1} \mathrm{dw}$, Ikemoto et al., 2005). Blood $\mathrm{Hg}$ concentrations higher than 3.0 $\mu \mathrm{g} \mathrm{g}^{-1} \mathrm{ww}$ (approximately $12 \mu \mathrm{g} \mathrm{g}^{-1} \mathrm{dw}$ ) were associated with negative breeding behaviour and output in adult common loons Gavia immer (Evers et al., 2008). A negative relationship between blood $\mathrm{Hg}$ concentrations and long-term breeding output was also shown in adult skuas at the same sites (Kerguelen Islands and Adélie Land, Goutte et al., 2014a). Chicks had no such high $\mathrm{Hg}$ burdens here, yet, sensitivity to $\mathrm{Hg}$ toxicity could depend on age-class.

Chick blood Se residues are normally less than $1 \mu \mathrm{g} \mathrm{g}^{-1}$ ww (about $4 \mu \mathrm{g} \mathrm{g}^{-1} \mathrm{dw}$ ) in terrestrial and aquatic birds, and less than $3 \mu \mathrm{g} \mathrm{g}^{-1} \mathrm{ww}$ (about $12 \mu \mathrm{g} \mathrm{g}^{-1} \mathrm{dw}$ ) in seabirds (Burger and Gochfeld, 1997; Ikemoto et al., 2005; Sebastiano et al., 2016, 2017). Hence, brown skua chicks from the southern Indian Ocean had up to a hundred-fold higher blood Se concentrations than most other birds, including those from environments with direct anthropogenic inputs of contaminants (de la Casa-Resino et al., 2014). Adults of some seabird species had blood Se concentrations of approximately 100-200 $\mathrm{g} \mathrm{g} \mathrm{g}^{-1} \mathrm{dw}$ (Anderson et al., 2010; Gonzalez-Solís et 
al., 2002), but contaminant burdens are usually higher in adults than in chicks (Bond and Diamond, 2009; Sebastiano et al., 2016, 2017). Hence Se concentrations in skua chicks from this study appear to be exceptionally high. Although essential within a narrow range of concentrations, Se can be toxic in birds, with a variety of adverse effects pertaining to reproduction, development of young, immunity and teratogenesis (Franson et al., 2000; Janz et al., 2010). Brown skua chicks had blood Se concentrations three to ten-fold higher than those of marine ducks displaying signs of Se toxicity (emaciation, increased oxidative stress, histological lesions, and mortality) following experimental dietary exposure (Franson et al., 2007). Skuas could have a much higher tolerance to high Se burdens when compared to other birds, and accordingly no clear signs of toxicity were seen in the sampled chicks.

Se-Hg interactions are often observed in the blood and internal tissues of marine predators, and the $\mathrm{Se}-\mathrm{Hg}$ antagonism is thought to be beneficial to counteract both $\mathrm{Hg}$ and Se negative effects (Cuvin-Aralar and Furness, 1991; Khan and Wang, 2009). In skua chicks, blood Hg and Se burdens were positively correlated. Furthermore, blood Se:Hg molar ratios were among the highest ever reported in seabirds, either in blood (e.g., Gonzalez-Solís et al., 2002; Wayland et al., 2001) or in other tissues (e.g., Dietz et al., 2000). This large molar Se excess in chick blood is likely beneficial when considering their high $\mathrm{Hg}$ exposure. Blood $\mathrm{Se}: \mathrm{Hg}$ molar ratios were three times lower in south polar skua chicks at Adélie Land than in brown skua chicks at Kerguelen, suggesting that the Antarctic population might be more at risk of $\mathrm{Hg}$ toxicity. Accordingly, long-term impacts on reproduction were more severe in south polar skuas at Adélie Land than in brown skuas at the Kerguelen Islands, despite blood Hg concentrations being four times lower in Antarctica (Goutte et al., 2014a). Although Se:Hg molar ratios could differ in chicks and adults, the relative concentrations of $\mathrm{Hg}$ and Se are likely not sufficient to prevent adverse effects in these populations. As such, long-term reproductive output and survival should be evaluated also in relation to Se. Clearly there is a need for more studies 
evaluating the concentrations and chemical forms of $\mathrm{Hg}$ and Se in skuas' blood and internal tissues, and the mechanisms and consequences of the Hg-Se interaction.

\subsubsection{Other trace elements and their interactions}

Apart from $\mathrm{Hg}$, other trace elements can negatively impact behaviour and physiology in seabirds. This is notably the case of the non-essential $\mathrm{Cd}$ and $\mathrm{Pb}$, which are associated with neurotoxicity, reduced reproduction and survival, and more subtle physiological effects in birds (Franson et al., 2000; Spahn and Sherry, 1999; Wilson et al., 2007). Cd and Pb were not detected in any chick in the present study, as shown in other high trophic level seabirds from the Southern Hemisphere (Anderson et al., 2010; Carravieri et al., 2014; Gonzalez-Solís et al., 2002). This is consistent with the low transfer potential of $\mathrm{Cd}$ and $\mathrm{Pb}$ in food webs (Sanchez-Hernandez, 2000; Walker et al., 2012). Similarly, the essential, but potentially toxic Ni was detected in a small proportion of individuals and concentrations were comparable or lower than those of other seabirds (Anderson et al., 2010; Burger and Gochfeld, 1997). Cd, Pb and Ni thus seem to be of minor toxicological concern for these skua chicks, but measure of internal organs' burdens should verify this statement. The essential metalloid As was detected in all Antarctic and Amsterdam skua chicks, and concentrations were comparable and relatively high, respectively, when compared to other seabird chicks worldwide (Baos et al., 2006; Burger and Gochfeld, 1997; de la Casa-Resino et al., 2014). As is especially toxic under its inorganic form (SanchezVirosta et al., 2015; Stanley et al., 1994), but marine biota mainly accumulates As under low toxicity organic forms (Kunito et al., 2008). Hence, further studies on the chemical forms of As and their effects in developing chicks are needed. Since actively regulated, $\mathrm{Cu}, \mathrm{Fe}, \mathrm{Mn}$ and $\mathrm{Zn}$ in blood were in the range of those found in polar seabirds (adults, Anderson et al., 2010; Fromant et al., 2016; Lucia et al., 2016). These elements are often correlated in blood and other tissues because of coexposure and co-regulation mechanisms (Fromant et al., 2016; Jerez et al., 
2013), and here this association was particularly true for $\mathrm{Cu}$ and Fe (Fig. 1). No evident essential element deficiency could be highlighted in these skua chicks.

\subsubsection{Persistent organic pollutants}

Of the several POPs that were targeted, only HCB and 4,4'-DDE had quantifiable residues in $>85 \%$ individuals, whereas the other POPs had very rare occurrence. Notably, even the most recalcitrant PCBs, such as congeners CB-153 and CB-180, which are usually abundant in Southern Ocean seabirds (e.g., Corsolini et al., 2011; Roscales et al., 2016), were detected in only a few individuals (Tables S3 in the SI). Previously, blood POPs concentrations in Southern Hemisphere seabird chicks were reported only in giant petrels from Antarctica (Colabuono et al., 2016). In comparison, skua chicks from Adélie Land, Crozet and Amsterdam Islands had similar blood $\mathrm{HCB}$ and 4,4'-DDE concentrations, while Kerguelen individuals had approximately two-fold higher burdens. When compared to great skua chicks (Northern Hemisphere, Bourgeon et al., 2013), blood 4,4'-DDE concentrations were lower at all sites, while blood HCB residues at the subantarctic and Antarctic sites were three-to ten-fold higher, respectively. This is not surprising, since $\mathrm{HCB}$, which was historically used in fungicide formulations but is also the by-product of other POPs' manufacture, is highly mobile and is one of the main POPs accumulating in Southern Ocean food webs (Bengtson Nash et al., 2007; Van den Brink, 1997). Notably, Kerguelen skua chicks had HCB burdens as high as those of adult wandering albatrosses (Crozet Islands, Carravieri et al., 2014), which suffer long-term breeding impairment from POPs exposure (Goutte et al., 2014b). Moreover, even low concentrations of POPs have detrimental effects in seabirds, such as endocrine and immune disruption (Bustnes, 2006; Bustnes et al., 2007, 2003; Tartu et al., 2015a,b), and impacts on demographic parameters including survival (Goutte et al., 2015a), suggesting potential toxicological concern in these skua populations. 


\subsection{Influence of site and feeding ecology on blood contaminant concentrations}

According to the latitudinal $\delta^{13} \mathrm{C}$ gradient in particulate organic matter from surface waters (François et al., 1993) that is reflected in the tissues of marine predators (Cherel and Hobson, 2007; Jaeger et al., 2010), skua chick blood $\delta^{13} \mathrm{C}$ values increased from Antarctic, to subantarctic, up to subtropical sites (Table 1). The low $\delta^{13} \mathrm{C}$ values of terrestrial items (Pisanu et al., 2011) preclude rats being significant prey of skuas at Crozet and Amsterdam Islands. At Kerguelen Islands, blood $\delta^{15} \mathrm{~N}$ values were consistent with a diet based on blue petrels and thinbilled prions (2.2\%o and $2.5 \%{ }^{15} \mathrm{Ndepleted}$, respectively, when compared to skua chicks; Cherel et al., 2014). On the other hand, skua chicks' blood $\delta^{15} \mathrm{~N}$ values were in agreement with crested and Adélie penguins being the main prey at Crozet and Adélie Land, respectively (Cherel, 2008; Cherel et al., 2007). Finally, the high blood $\delta^{15} \mathrm{~N}$ values of Amsterdam skua chicks likely reflect two factors: 1) the increase of $\delta^{15} \mathrm{~N}$ signature at the base of the food web north of the subtropical front (Altabet and Francois, 1994) and 2) the potential presence of scavenged marine mammals in addition to seabirds in skua chicks' diet (Cherel and Hobson, 2007; Cherel et al., 2008). In conclusion, blood isotopic values indicated that 1) skua chicks' diet is based largely on marine resources, with potential contributions of terrestrial prey being negligible, and 2) skua chicks occupy a high trophic position within their food webs at each site.

\subsection{1. $\mathrm{Hg}$, Se and other trace elements}

Skua chicks had strong site-specific differences in blood Hg and Se burdens, and overall in their trace element pattern. Blood $\mathrm{Hg}$ concentrations increased from chicks in Antarctica to chicks at the subantarctic and subtropical sites, with a factor of eight between Adélie Land and Amsterdam populations (Fig. 2). Site and feeding habitat $\left(\delta^{13} \mathrm{C}\right)$ played a major role in explaining this pattern, suggesting geographical differences in $\mathrm{Hg}$ transfer to skuas in the southern Indian Ocean. This latitudinal trend is strongly supported at the population and species 
levels, by previous results in other seabird species occupying different trophic positions (Carravieri et al., 2014, 2016; Goutte et al., 2014a). Yet, it is not consistent with empirical evidence of higher $\mathrm{Hg}$ deposition rates at Antarctic latitudes, and higher dissolved methyl-Hg concentrations, the bioavailable and most toxic form of $\mathrm{Hg}$, in Antarctic rather than in subtropical waters (Cossa et al., 2011). Skua chick blood Se burdens showed a similar geographical trend to $\mathrm{Hg}$ concentrations, decreasing from subtropical to Antarctic latitudes, with the exception of the Kerguelen population (Fig. 2). The comparable geographical pattern between blood $\mathrm{Hg}$ and Se concentrations could be the result of i) a similar latitudinal gradient in Se concentrations in southern Indian Ocean food webs, ii) a preferential retention of Se in skua chicks in order to counteract $\mathrm{Hg}$ toxicity, and/or iii) a dietary co-exposure. The disproportionally high blood Se burdens of Kerguelen skua chicks seem to support the latter explanation. Indeed, their main prey (blue petrels, Section 2.2) have high Se burdens in their tissues (Anderson et al., 2010; authors' unpublished data). Blue petrels had also high liver and kidney burdens of $\mathrm{Cd}$ (Bocher et al., 2003), which was not reflected in the skua chicks blood Cd concentrations. This could be linked to two non-exclusive factors: 1) the low assimilation efficiency of $\mathrm{Cd}$ (Walker et al., 2012) and 2) the preferential storage of $\mathrm{Cd}$ in internal tissues (in particular in the kidneys, e.g., Fromant et al., 2016; Kojadinovic et al., 2007), with circulating concentrations remaining low. With respect to trace element patterns, Amsterdam Island and Adélie Land skua chicks showed intriguing results. At Amsterdam Island, concentrations of $\mathrm{As}, \mathrm{Cu}, \mathrm{Mn}, \mathrm{Se}$ and $\mathrm{Zn}$ were relatively high. A natural richness in trace elements in food webs at this location could be triggered by local factors such as active volcanism, known to increase metal concentrations in the marine environment (Bustamante et al., 2003; Monod et al., 1996; SCOR Group, 2007). Further studies on the skuas' diet, and on trace element burdens in other seabirds and marine mammals breeding on the island, could clarify whether this metallic pattern is generalised to all biota or is specific to the skuas. On the 
other hand, skua chicks at Adélie Land had relatively high concentrations of As. This could result from high concentrations and/or bioavailability of As in sediments at Antarctic sites, as reflected in the tissues of some fish and seabird species (Anderson et al., 2010; Goutte et al., 2015b).

\subsubsection{Persistent organic pollutants}

Global distillation mechanisms predict that organic compounds have stronger deposition rates at high latitudes, with most volatile compounds becoming more abundant than heavier ones (Barber et al., 2005; Dachs et al., 2002; Van den Brink, 1997; Wania and Mackay, 1996). Here, interpretation of geographical trends in skua chick POPs burdens is made difficult by the high number of non-detects. Yet, blood HCB and 4,4'-DDE concentrations showed significant sitespecific differences. In particular, skua chicks had increasing HCB burdens from the subtropical to the subantarctic sites, in agreement with results in the wandering albatross from the same oceanic region (Carravieri et al., 2014). Furthermore, the contribution of the highly mobile HCB to the $\sum 18 \mathrm{POP}$ gradually increased from the subtropics down to Antarctica (Fig. 2), as shown also in giant petrels (Roscales et al., 2016). These results support the influence of global distillation mechanisms on POP exposure in Southern Ocean predators. Conversely, both blood HCB and 4,4'-DDE concentrations were low at the Antarctic site. Skua chicks at Adélie Land rely on prey that depends on the local neritic food web. Indeed, Adélie penguin chicks, an important prey item for skua chicks at this site (Section 2.2.), feed mainly on pelagic fish and euphausiids caught in neritic waters (Cherel, 2008). POPs' food web uptake and biomagnification may be different in this neritic ecosystem than in open oceanic waters. In addition, skua chicks at Kerguelen Islands had high quantity and diversity of POPs when compared to the other populations. This pattern is likely related to the consumption of small procellariiform seabirds, which have high POPs concentrations and diversity in their tissues (Fromant et al., 2016) and blood (authors' unpublished data). Overall, these results suggest that 
both global distillation and consumption of specific prey types play a role in driving POPs exposure in top predators in the southern Indian Ocean.

\section{Conclusion}

This study confirms 1) the strong latitudinal gradient in $\mathrm{Hg}$ concentrations in southern Indian Ocean predators' tissues (Carravieri et al., 2014, 2016), and 2) the abundance of HCB in biota from high latitudes of the Southern Hemisphere, despite decade long regulation at a global level (Bengtson Nash et al., 2007). Importantly, results highlight 1) very high blood $\mathrm{Hg}$ and Se concentrations that raise toxicological concerns, and 2) the importance of knowing precisely the diet of seabirds to interpret their contaminant burdens. In addition, significant knowledge gaps were highlighted by this study, opening important perspectives. For example, the developing phase of chicks and juveniles is known to be particularly vulnerable to toxic effects of contaminants (Walker et al., 2012; Wolfe et al., 1998), but it is surprisingly poorly studied in wild populations (but see Jenssen et al., 2010; Murvoll et al., 2006; for POPs; and Ackerman et al., 2008; Monteiro and Furness, 2001; for Hg). Southern Indian Ocean skuas appear to be ideal models for toxicological studies on trace elements and POPs in the wild, because they have contrasted contaminant burdens, yet are ecologically and taxonomically closely-related. This would limit potential dietary and physiological bias. In-depth studies on potential toxicity are particularly urgent for $\mathrm{As}, \mathrm{Hg}, \mathrm{Se}$ and $\mathrm{HCB}$ in these skua populations. On the other hand, biogeochemical studies on contaminant distribution and transfer to food webs in the southern Indian Ocean are critically needed to explain the latitudinal patterns highlighted here. Attention should be paid to low trophic level organisms, which play a critical role in the exposure to seabirds and other predators to contaminants.

\section{Conflict of interest}

The authors declare that there are no conflicts of interest. 
Acknowledgements: The present work was supported financially and logistically by the Région Poitou-Charentes through a $\mathrm{PhD}$ grant to $\mathrm{AC}$, and by the Agence Nationale de la Recherche (program POLARTOP, O. Chastel), the Institut Polaire Français Paul Emile Victor (IPEV, program no. 109, H. Weimerskirch) and the Terres Australes et Antarctiques Françaises (TAAF). The Aquitaine Region and the European Union (CPER A2E project) are acknowledged for their financial support. Europe is moving in Aquitaine with the European Regional Development Fund. The authors thank J-B Thiébot and all the fieldworkers that contributed to the collection of samples. The authors also thank T. Lacombe for the skua picture of the graphical abstract. The authors are grateful to the Plateforme Analyses Elémentaires and the Plateforme Analyses Isotopiques of the LIENSs laboratory for the access to their analytical facilities, and in particular to G. Guillou for running stable isotope analysis. Field procedures were authorised by the Ethics Committee of IPEV and by the Comité de l'Environnement Polaire.

\section{References}

Ackerman, J.T., Takekawa, J.Y., Eagles-Smith, C.A., Iverson, S.A., 2008. Mercury contamination and effects on survival of American avocet and black-necked stilt chicks in San Francisco Bay. Ecotoxicology 17, 103-116. doi:10.1007/s10646-007-0164-y

Altabet, M.A., Francois, R., 1994. Sedimentary nitrogen isotopic ratio as a recorder for surface ocean nitrate utilization. Glob. Biogeochem. Cycles 8, 103-116. doi:10.1029/93GB03396

Anderson, O.R.J., Phillips, R.A., Shore, R.F., McGill, R.A.R., McDonald, R.A., Bearhop, S., 2010. Element patterns in albatrosses and petrels: influence of trophic position, foraging range, and prey type. Environ. Pollut. 158, 98-107.

Baos, R., Bias, J., Bortolotti, G.R., Marchant, T.A., Hiraldo, F., 2006. Adrenocortical Response to Stress and Thyroid Hormone Status in Free-Living Nestling White Storks (Ciconia ciconia) Exposed to Heavy Metal and Arsenic Contamination. Environ. Health Perspect. 114, 1497-1501.

Barber, J.L., Sweetman, A.J., van Wijk, D., Jones, K.C., 2005. Hexachlorobenzene in the global environment: Emissions, levels, distribution, trends and processes. Sci. Total Environ. 349, 1-44. doi:10.1016/j.scitotenv.2005.03.014

Bargagli, R., 2008. Environmental contamination in Antarctic ecosystems. Sci. Total Environ. 400, 212-226.

Bearhop, S., Waldron, S., Thompson, D., Furness, R., 2000. Bioamplification of Mercury in Great Skua Catharacta skua Chicks: the Influence of Trophic Status as Determined by Stable Isotope Signatures of Blood and Feathers. Mar. Pollut. Bull. 40, 181-185.

Bengtson Nash, S., Poulsen, A.H., Sb, K., Mc, S., 2007. Hexachlorobenzene in a Southern Ocean food web; Contaminant accumulation \& global comparisons. Organohalogen Compd. 69, 154. 
Blévin, P., Carravieri, A., Jaeger, A., Chastel, O., Bustamante, P., Cherel, Y., 2013. Wide range of mercury contamination in chicks of Southern Ocean seabirds. PLoS ONE 8, e54508. doi:10.1371/journal.pone.0054508

Bocher, P., Caurant, F., Miramand, P., Cherel, Y., Bustamante, P., 2003. Influence of the diet on the bioaccumulation of heavy metals in zooplankton-eating petrels at Kerguelen archipelago, Southern Indian Ocean. Polar Biol. 26, 759-767.

Bond, A.L., Diamond, A.W., 2009. Mercury concentrations in seabird tissues from Machias Seal Island, New Brunswick, Canada. Sci. Total Environ. 407, 4340-4347.

Borgå, K., Campbell, L., Gabrielsen, G.W., Norstrom, R.J., Muir, D.C.G., Fisk, A.T., 2006. Regional and species specific bioaccumulation of major and trace elements in Arctic seabirds. Environ. Toxicol. Chem. 25, 2927-2936. doi:10.1897/05-574R1.1

Bourgeon, S., Leat, E.K., Furness, R.W., Borgå, K., Hanssen, S.A., Bustnes, J.O., 2013. Dietary versus maternal sources of organochlorines in top predator seabird chicks: an experimental approach. Environ. Sci. Technol. 47, 5963-5970.

Brasso, R.L., Chiaradia, A., Polito, M.J., Raya Rey, A., Emslie, S.D., 2015. A comprehensive assessment of mercury exposure in penguin populations throughout the Southern Hemisphere: Using trophic calculations to identify sources of population-level variation. Mar. Pollut. Bull. 97, 408-418. doi:10.1016/j.marpolbul.2015.05.059

Braune, B.M., Gaston, A.J., Hobson, K.A., Gilchrist, H.G., Mallory, M.L., 2014. Changes in Food Web Structure Alter Trends of Mercury Uptake at Two Seabird Colonies in the Canadian Arctic. Environ. Sci. Technol. 48, 13246-13252. doi:10.1021/es5036249

Burger, J., Gochfeld, M., 2004. Marine birds as sentinels of environmental pollution. EcoHealth $1,263-274$.

Burger, J., Gochfeld, M., 1997. Risk, Mercury Levels, and Birds: Relating Adverse Laboratory Effects to Field Biomonitoring. Environ. Res. 75, 160-172. doi:10.1006/enrs.1997.3778

Burnham, K.P., Anderson, D.R., 2002. Model selection and multi-model inference: a practical information-theoretic approach, Second Edition. ed. Springer, New York.

Bustamante, P., Bocher, P., Cherel, Y., Miramand, P., Caurant, F., 2003. Distribution of trace elements in the tissues of benthic and pelagic fish from the Kerguelen Islands. Sci. Total Environ. 313, 25-39.

Bustamante, P., Lahaye, V., Durnez, C., Churlaud, C., Caurant, F., 2006. Total and organic Hg concentrations in cephalopods from the North Eastern Atlantic waters: Influence of geographical origin and feeding ecology. Sci. Total Environ. 368, 585-596.

Bustnes, J.O., 2006. Pinpointing Potential Causative Agents in Mixtures of Persistent Organic Pollutants in Observational Field Studies: A Review of Glaucous Gull Studies. J. Toxicol. Environ. Health A 69, 97-108. doi:10.1080/15287390500259301

Bustnes, J.O., Erikstad, K.E., Skaare, J.U., Bakken, V., Mehlum, F., 2003. Ecological effects of organochlorine pollutants in the Arctic: A study of the Glaucous Gull. Ecol. Appl. 13, 504-515. doi:10.1890/1051-0761(2003)013[0504:EEOOPI]2.0.CO;2

Bustnes, J.O., Tveraa, T., Varpe, Ø., Henden, J.A., Skaare, J.U., 2007. Reproductive performance and organochlorine pollutants in an Antarctic marine top predator: The south polar skua. Environ. Int. 33, 911-918. doi:10.1016/j.envint.2007.04.010

Carravieri, A., Bustamante, P., Tartu, S., Meillère, A., Labadie, P., Budzinski, H., Peluhet, L., Barbraud, C., Weimerskirch, H., Chastel, O., Cherel, Y., 2014. Wandering Albatrosses Document Latitudinal Variations in the Transfer of Persistent Organic Pollutants and Mercury to Southern Ocean Predators. Environ. Sci. Technol. 48, 14746-14755. doi:10.1021/es504601m

Carravieri, A., Cherel, Y., Jaeger, A., Churlaud, C., Bustamante, P., 2016. Penguins as bioindicators of mercury contamination in the southern Indian Ocean: geographical and temporal trends. Environ. Pollut. 213, 195-205. doi:10.1016/j.envpol.2016.02.010 
Carvalho, P.C., Bugoni, L., McGill, R.A., Bianchini, A., 2013. Metal and selenium concentrations in blood and feathers of petrels of the genus Procellaria. Environ. Toxicol. Chem. 32, 1641-1648.

Casa-Resino, I. de la, Hernández-Moreno, D., Castellano, A., Pérez-López, M., Soler, F., 2014. Breeding near a landfill may influence blood metals $(\mathrm{Cd}, \mathrm{Pb}, \mathrm{Hg}, \mathrm{Fe}, \mathrm{Zn})$ and metalloids (Se, As) in white stork (Ciconia ciconia) nestlings. Ecotoxicology 23, 1377-1386. doi:10.1007/s10646-014-1280-0

Cherel, Y., 2008. Isotopic niches of emperor and Adélie penguins in Adélie Land, Antarctica. Mar. Biol. 154, 813-821.

Cherel, Y., Hobson, K.A., 2007. Geographical variation in carbon stable isotope signatures of marine predators: a tool to investigate their foraging areas in the Southern Ocean. Mar. Ecol. Prog. Ser. 329, 281-287.

Coale, K.H., Johnson, K.S., Fitzwater, S.E., Gordon, M.R., Tanner, S., Chavez, F.P., Ferioli, L., Sakamoto, C., Rogers, P., Millero, F., Steinberg, P., Nightingale, P., Cooper, D., Cochlan, W.P., Landry, M.R., Constantinou, J., Rollwagen, G., Trasvina, A., Kudela, R., 1996. A massive phytoplankton bloom induced by an ecosystem-scale iron fertilization experiment in the equatorial Pacific Ocean. Nature 383, 495-500.

Coeurdassier, M., Fritsch, C., Faivre, B., Crini, N., Scheifler, R., 2012. Partitioning of Cd and $\mathrm{Pb}$ in the blood of European blackbirds (Turdus merula) from a smelter contaminated site and use for biomonitoring. Chemosphere 87, 1368-1373.

Colabuono, F.I., Vander Pol, S.S., Huncik, K.M., Taniguchi, S., Petry, M.V., Kucklick, J.R., Montone, R.C., 2016. Persistent organic pollutants in blood samples of Southern Giant Petrels (Macronectes giganteus) from the South Shetland Islands, Antarctica. Environ. Pollut. 216, 38-45. doi:10.1016/j.envpol.2016.05.041

Corsolini, S., Borghesi, N., Ademollo, N., Focardi, S., 2011. Chlorinated biphenyls and pesticides in migrating and resident seabirds from East and West Antarctica. Environ. Int. 37, 1329-1335.

Cossa, D., Heimbürger, L.E., Lannuzel, D., Rintoul, S.R., Butler, E.C.V., Bowie, A.R., Averty, B., Watson, R.J., Remenyi, T., 2011. Mercury in the Southern Ocean. Geochim. Cosmochim. Acta 75, 4037-4052.

Cuvin-Aralar, M.L.A., Furness, R.W., 1991. Mercury and selenium interaction: A review. Ecotoxicol. Environ. Saf. 21, 348-364. doi:10.1016/0147-6513(91)90074-Y

Dachs, J., Lohmann, R., Ockenden, W.A., Méjanelle, L., Eisenreich, S.J., Jones, K.C., 2002. Oceanic biogeochemical controls on global dynamics of persistent organic pollutants. Environ. Sci. Technol. 36, 4229-4237.

Dietz, R., Riget, F., Born, E.W., 2000. An assessment of selenium to mercury in Greenland marine animals. Sci. Total Environ. 245, 15-24. doi:10.1016/S0048-9697(99)00430-1

Eagles-Smith, C.A., Ackerman, J.T., Yee, J., Adelsbach, T.L., 2009. Mercury demethylation in waterbird livers: dose-response thresholds and differences among species. Environ. Toxicol. Chem. 28, 568-577.

Elliott, J.E., Elliott, K.H., 2013. Tracking Marine Pollution. Science 340, 556. doi:10.1126/science. 1235197

Evers, D.C., Savoy, L.J., DeSorbo, C.R., Yates, D.E., Hanson, W., Taylor, K.M., Siegel, L.S., Cooley Jr, J.H., Bank, M.S., Major, A., 2008. Adverse effects from environmental mercury loads on breeding common loons. Ecotoxicology 17, 69-81.

Fevold, B.M., Meyer, M.W., Rasmussen, P.W., Temple, S.A., 2003. Bioaccumulation Patterns and Temporal Trends of Mercury Exposure in Wisconsin Common Loons. Ecotoxicology 12, 83-93. doi:10.1023/A:1022545130918 
François, R., Altabet, M.A., Goericke, R., 1993. Changes in the $\delta^{13} \mathrm{C}$ of surface water particulate matter across the Subtropical Convergence in the SW Indian Ocean. Global Biogeochem. Cycles 7, 627-644

Franson, J.C., Hoffman, D.J., Wells-Berlin, A., Perry, M.C., Shearn-Bochsler, V., Finley, D.L., Flint, P.L., Hollmén, T., 2007. Effects of Dietary Selenium on Tissue Concentrations, Pathology, Oxidative Stress, and Immune Function in Common Eiders (Somateria mollissima). J. Toxicol. Environ. Health A 70, 861-874. doi:10.1080/15287390701212760

Franson, J.C., Hollmen, T., Poppenga, R.H., Hario, M., Kilpi, M., Smith, M.R., 2000. Selected trace elements and organochlorines: Some findings in blood and eggs of nesting common eiders (Somateria mollissima) from Finland. Environ. Toxicol. Chem. 19, 1340-1347. doi:10.1002/etc.5620190517

Fromant, A., Carravieri, A., Bustamante, P., Labadie, P., Budzinski, H., Peluhet, L., Churlaud, C., Chastel, O., Cherel, Y., 2016. Wide range of metallic and organic contaminants in various tissues of the Antarctic prion, a planktonophagous seabird from the Southern Ocean. Sci. Total Environ. 544, 754-764. doi:10.1016/j.scitotenv.2015.11.114

Furness, R.W., 1987. The Skuas. T. \& A. D. Poyser, Calton.

González-Solís, J., Sanpera, C., Ruiz, X., 2002. Metals and selenium as bioindicators of geographic and trophic segregation in giant petrels Macronectes spp. Mar. Ecol. Prog. Ser. 244, 257-264.

Goutte, A., Barbraud, C., Herzke, D., Bustamante, P., Angelier, F., Tartu, S., Clément-Chastel, C., Moe, B., Bech, C., Gabrielsen, G.W., Bustnes, J.O., Chastel, O., 2015a. Survival rate and breeding outputs in a high Arctic seabird exposed to legacy persistent organic pollutants and mercury. Environ. Pollut. 200, 1-9. doi:10.1016/j.envpol.2015.01.033

Goutte, A., Bustamante, P., Barbraud, C., Delord, K., Weimerskirch, H., Chastel, O., 2014a. Demographic responses to mercury exposure in two closely-related Antarctic top predators. Ecology 95, 1075-1086. doi:10.1890/13-1229.1

Goutte, A., Barbraud, C., Meillère, A., Carravieri, A., Bustamante, P., Labadie, P., Budzinski, H., Delord, K., Cherel, Y., Weimerskirch, H., Chastel, O., 2014b. Demographic consequences of heavy metals and persistent organic pollutants in a vulnerable longlived bird, the wandering albatross. Proc. R. Soc. B Biol. Sci. 281, 20133313. doi:10.1098/rspb.2013.3313

Goutte, A., Cherel, Y., Churlaud, C., Ponthus, J.-P., Massé, G., Bustamante, P., 2015b. Trace elements in Antarctic fish species and the influence of foraging habitats and dietary habits on mercury levels. Sci. Total Environ. 538, 743-749. doi:10.1016/j.scitotenv.2015.08.103

Henriksen, E.O., Gabrielsen, G.W., Skaare, J.U., 1998. Validation of the use of blood samples to assess tissue concentrations of organochlorines in glaucous gulls, Larus hyperboreus. Chemosphere 37, 2627-2643.

Hipfner, J.M., Hobson, K.A., Elliott, J.E., 2011. Ecological factors differentially affect mercury levels in two species of sympatric marine birds of the North Pacific. Sci. Total Environ. 409, 1328-1335.

Ikemoto, T., Kunito, T., Tanabe, S., Tsurumi, M., Sato, F., Oka, N., 2005. Non-destructive monitoring of trace element levels in short-tailed albatrosses (Phoebastria albatrus) and black-footed albatrosses (Phoebastria nigripes) from Torishima Island, Japan using eggs and blood. Mar. Pollut. Bull., 4th International Conference on Marine Pollution and Ecotoxicology4th International Conference on Marine Pollution and Ecotoxicology 51, 889-895. doi:10.1016/j.marpolbul.2005.06.003 
Jaeger, A., Connan, M., Richard, P., Cherel, Y., 2010. Use of stable isotopes to quantify seasonal changes of trophic niche and levels of population and individual specialisation in seabirds. Mar. Ecol. Prog. Ser. 401, 269-277.

Janz, D.M., DeForest, D.K., Brooks, M.L., Chapman, P.M., Gilron, G., Hoff, D., Hopkins, W.A., McIntyre, D.O., Mebane, C.A., Palace, V.P., Skorupa, J.P., Wayland, M., 2010. Selenium toxicity to aquatic organisms, in: Ecological Assessment of Selenium in the Aquatic Envrionment.

Jenssen, B.M., Aarnes, J.B., Murvoll, K.-M., Herzke, D., Nygård, T., 2010. Fluctuating wing asymmetry and hepatic concentrations of persistent organic pollutants are associated in European shag (Phalacrocorax aristotelis) chicks. Sci. Total Environ. 408, 578-585. doi:10.1016/j.scitotenv.2009.10.036

Jerez, S., Motas, M., Benzal, J., Diaz, J., Barbosa, A., 2013. Monitoring trace elements in Antarctic penguin chicks from South Shetland Islands, Antarctica. Mar. Pollut. Bull. 69, 67-75. doi:10.1016/j.marpolbul.2013.01.004

Kahle, S., Becker, P.H., 1999. Bird blood as bioindicator for mercury in the environment. Chemosphere 39, 2451-2457.

Keller, J.M., Kucklick, J.R., McClellan-Green, P.D., 2004. Organochlorine contaminants in loggerhead sea turtle blood: extraction techniques and distribution among plasma and red blood cells. Arch. Environ. Contam. Toxicol. 46, 254-264.

Khan, M.A.K., Wang, F., 2009. Mercury-selenium compounds and their toxicological significance: Toward a molecular understanding of the mercury-selenium antagonism.

Environ. Toxicol. Chem. 28, 1567-1577. doi:10.1897/08-375.1

Kojadinovic, J., Corre, M.L., Cosson, R.P., Bustamante, P., 2007. Trace Elements in Three Marine Birds Breeding on Reunion Island (Western Indian Ocean): Part 1-Factors Influencing Their Bioaccumulation. Arch. Environ. Contam. Toxicol. 52, 418-430. doi:10.1007/s00244-005-0225-2

Kojadinovic, J., Jackson, C.H., Cherel, Y., Jackson, G.D., Bustamante, P., 2011. Multielemental concentrations in the tissues of the oceanic squid Todarodes filippovae from Tasmania and the southern Indian Ocean. Ecotoxicol. Environ. Saf. 74, 1238-1249. doi:10.1016/j.ecoenv.2011.03.015

Kunito, T., Kubota, R., Fujihara, J., Agusa, T., Tanabe, S., 2008. Arsenic in marine mammals, seabirds, and sea turtles. Rev. Environ. Contam. Toxicol. 195, 31-69.

Lucia, M., Strøm, H., Bustamante, P., Gabrielsen, G.W., 2016. Trace Element Concentrations in Relation to the Trophic Behaviour of Endangered Ivory Gulls (Pagophila eburnea) During Their Stay at a Breeding Site in Svalbard. Arch. Environ. Contam. Toxicol. 71, 518-529. doi:10.1007/s00244-016-0320-6

Matthews, H.B., Surles, J.R., Carver, J.G., Anderson, M.W., 1984. Halogenated biphenyl transport by blood components. Fundam. Appl. Toxicol. 4, 420-428. doi:10.1016/02720590(84)90199-4

Monod, J., Arnaud, P.M., Arnoux, A., 1996. Speciation analysis of mercury compounds in marine biota of Saint- Paul and Amsterdam islands (Indian ocean) by GC- AES. Toxicol. Environ. Chem. 57, 235-248. doi:10.1080/02772249609358391

Monteiro, L.R., Furness, R.W., 2001. Kinetics, dose-response, excretion, and toxicity of methylmercury in free-living Cory's shearwater chicks. Environ. Toxicol. Chem. 20, 1816-1823. doi:10.1002/etc.5620200827

Mougeot, F., Genevois, F., Bretagnolle, V., 1998. Predation on burrowing petrels by the brown skua (Catharacta skua lönnbergi) at Mayes Island, Kerguelen. J. Zool. 244, 429-438.

Murvoll, K.M., Skaare, J.U., Anderssen, E., Jenssen, B.M., 2006. Exposure and effects of persistent organic pollutants in european shag (Phalacrocorax aristotelis) hatchlings 
from the coast of Norway. Environ. Toxicol. Chem. 25, 190-198. doi:10.1897/04333R.1

Nizzetto, L., Lohmann, R., Gioia, R., Dachs, J., Jones, K.C., 2010. Atlantic Ocean surface waters buffer declining atmospheric concentrations of persistent organic pollutants. Environ. Sci. Technol. 44, 6978-6984.

Olsen, K.M., Larsson, H., 1997. Skuas and jaegers: a guide to the skuas and jaegers of the world. Pica Press, Mountfield.

Pućko, M., Burt, A., Walkusz, W., Wang, F., Macdonald, R.W., Rysgaard, S., Barber, D., Tremblay, J.-E., Stern, G.A., 2014. Transformation of mercury at the bottom of the Arctic food web: an overlooked puzzle in the mercury exposure narrative. Environ. Sci. Technol. 48, 7280-7288.

R Core Team, 2015. R: a language and environment for statistical computing. R Foundation for Statistical Computing, Vienna, Austria.

Rauch, J.N., Pacyna, J.M., 2009. Earth's global Ag, Al, Cr, Cu, Fe, Ni, Pb, and Zn cycles. Glob. Biogeochem. Cycles 23, GB2001. doi:10.1029/2008GB003376

Roscales, J.L., González-Solís, J., Zango, L., Ryan, P.G., Jiménez, B., 2016. Latitudinal exposure to DDTs, HCB, PCBs, PBDEs and DP in giant petrels (Macronectes spp.) across the Southern Ocean. Environ. Res. 148, 285-294. doi:10.1016/j.envres.2016.04.005

Sanchez-Hernandez, J., 2000. Trace element contamination in Antarctic ecosystems. Rev. Environ. Contam. Toxicol. 166, 83-127.

Sánchez-Virosta, P., Espín, S., García-Fernández, A.J., Eeva, T., 2015. A review on exposure and effects of arsenic in passerine birds. Sci. Total Environ. 512-513, 506-525. doi:10.1016/j.scitotenv.2015.01.069

SCOR Group, 2007. GEOTRACES - An international study of the global marine biogeochemical cycles of trace elements and their isotopes. Chem. Erde - Geochem. 67, 85-131. doi:10.1016/j.chemer.2007.02.001

Sebastiano, M., Bustamante, P., Costantini, D., Eulaers, I., Malarvannan, G., MendezFernandez, P., Churlaud, C., Blévin, P., Hauselmann, A., Dell'Omo, G., Covaci, A., Eens, M., Chastel, O., 2016. High levels of mercury and low levels of persistent organic pollutants in a tropical seabird in French Guiana, the Magnificent frigatebird, Fregata magnificens. Environ. Pollut. 214, 384-393. doi:10.1016/j.envpol.2016.03.070

Sen, I.S., Peucker-Ehrenbrink, B., 2012. Anthropogenic disturbance of element cycles at the Earth's surface. Environ. Sci. Technol. 46, 8601-8609.

Spahn, S.A., Sherry, T.W., 1999. Cadmium and Lead Exposure Associated with Reduced Growth Rates, Poorer Fledging Success of Little Blue Heron Chicks (Egretta caerulea) in South Louisiana Wetlands. Arch. Environ. Contam. Toxicol. 37, 377-384. doi:10.1007/s002449900528

Stahl, J.-C., Mougin, J.-L., 1986. La ségrégation alimentaire chez le Skua subantarctique Stercorarius skua lönnbergi. Oiseau Rev. Francaise Ornithol. 56, 193-208.

Stanley, T.R., Spann, J.W., Smith, G.J., Rosscoe, R., 1994. Main and interactive effects of arsenic and selenium on mallard reproduction and duckling growth and survival. Arch. Environ. Contam. Toxicol. 26, 444-451. doi:10.1007/BF00214145

Szumiło, E., Szubska, M., Meissner, W., Bełdowska, M., Falkowska, L., 2013. Mercury in immature and adults Herring Gulls (Larus argentatus) wintering on the Gulf of Gdańsk area. Oceanol. Hydrobiol. Stud. 42, 260-267. doi:10.2478/s13545-013-0082-y

Tapie, N., Menach, K.L., Pasquaud, S., Elie, P., Devier, M.H., Budzinski, H., 2011. PBDE and PCB contamination of eels from the Gironde estuary: from glass eels to silver eels. Chemosphere 83, 175-185. 
Tartu, S., Angelier, F., Bustnes, J.O., Moe, B., Hanssen, S.A., Herzke, D., Gabrielsen, G.W., Verboven, N., Verreault, J., Labadie, P., Budzinski, H., Wingfield, J.C., Chastel, O., 2015a. Polychlorinated biphenyl exposure and corticosterone levels in seven polar seabird species. Environ. Pollut. 197, 173-180. doi:10.1016/j.envpol.2014.12.007

Tartu, S., Angelier, F., Wingfield, J.C., Bustamante, P., Labadie, P., Budzinski, H., Weimerskirch, H., Bustnes, J.O., Chastel, O., 2015b. Corticosterone, prolactin and egg neglect behavior in relation to mercury and legacy POPs in a long-lived Antarctic bird. Sci. Total Environ. 505, 180-188. doi:10.1016/j.scitotenv.2014.10.008

Tavares, S., Xavier, J.C., Phillips, R.A., Pereira, M.E., Pardal, M.A., 2013. Influence of age, sex and breeding status on mercury accumulation patterns in the wandering albatross Diomedea exulans. Environ. Pollut. 181, 315-320.

UNEP. Official Website of the Stockholm Convention http://chm.pops.int/Home/tabid/2121/mctl/ViewDetails/EventModID/871/EventID/51 4/xmid/6921/Default.aspx.

Van den Brink, N.W., 1997. Directed transport of volatile organochlorine pollutants to polar regions: the effect on the contamination pattern of Antarctic seabirds. Sci. Total Environ. 198, 43-50.

Walker, C.H., Sibly, R.M., Hopkin, S.P., Peakall, D.B., 2012. Principles of Ecotoxicology, Fourth Edition. CRC Press.

Wania, F., Mackay, D., 1996. Peer reviewed: tracking the distribution of persistent organic pollutants. Environ. Sci. Technol. 30, 390A-396A.

Wayland, M., Garcia-Fernandez, A.J., Neugebauer, E., Gilchrist, H.G., 2001. Concentrations of Cadmium, Mercury and Selenium in Blood, Liver and Kidney of Common Eider Ducks from the Canadian Arctic. Environ. Monit. Assess. 71, 255-267. doi:10.1023/A:1011850000360

Wilson, H.M., Flint, P.L., Powell, A.N., 2007. Coupling contaminants with demography: Effects of lead and selenium in Pacific common eiders. Environ. Toxicol. Chem. 26, 1410-1417. doi:10.1897/06-537R.1

Wolfe, M.F., Schwarzbach, S., Sulaiman, R.A., 1998. Effects of mercury on wildlife: a comprehensive review. Environ. Toxicol. Chem. 17, 146-160.

Zuur, A.F., Ieno, E.N., Walker, N., 2009. Mixed Effects Models and Extensions in Ecology with R. Springer. 
Table 1. Blood cell $\mathrm{Cu}, \mathrm{Fe}, \mathrm{Hg}$, Se $\left(\mu \mathrm{g} \mathrm{g}^{-1} \mathrm{dw}\right.$ ), plasma HCB and 4,4'-DDE (ng g${ }^{-1} \mathrm{ww}$ ) and blood cells $\delta^{13} \mathrm{C}$ and $\delta^{15} \mathrm{~N}$ values (\%) in chicks of four skua populations from the southern Indian Ocean. Values are mean \pm SD. Letters indicate significant differences (trace elements and stable isotope values: Tukey's HSD, all $p<0.001$; HCB and 4,4'-DDE: multiple comparisons of means through Tukey contrasts of the best selected models (Table 2), $p<0.05$ ). Abbreviation: df, detection frequency.

\begin{tabular}{|c|c|c|c|c|c|}
\hline & \multirow[b]{2}{*}{$\begin{array}{l}\mathrm{df} \\
(\%)\end{array}$} & \multirow{2}{*}{$\begin{array}{l}\text { South polar skua } \\
\text { Adélie Land } \\
\text { Antarctica }(\mathrm{N}=11) \\
\end{array}$} & \multicolumn{3}{|c|}{ Brown skua } \\
\hline & & & $\begin{array}{c}\text { Kerguelen } \\
\text { subantarctic }(\mathrm{N}=10)\end{array}$ & $\begin{array}{c}\text { Crozet } \\
\text { subantarctic }(\mathrm{N}=10) \\
\end{array}$ & $\begin{array}{c}\text { Amsterdam } \\
\text { subtropics }(\mathrm{N}=10)\end{array}$ \\
\hline $\mathbf{C u}$ & 100 & $0.99 \pm 0.16^{\mathrm{a}}$ & $0.61 \pm 0.07^{\mathrm{b}}$ & $0.87 \pm 0.06^{\mathrm{a}}$ & $1.20 \pm 0.14^{\mathrm{c}}$ \\
\hline $\mathrm{Fe}$ & 100 & $2397 \pm 80^{\mathrm{a}}$ & $2276 \pm 68^{\mathrm{b}, \mathrm{c}}$ & $2201 \pm 119^{b}$ & $2362 \pm 89^{\mathrm{a}, \mathrm{c}}$ \\
\hline $\mathbf{H g}$ & 100 & $0.51 \pm 0.1^{\mathrm{a}}$ & $2.31 \pm 0.33^{\mathrm{b}}$ & $1.66 \pm 1.20^{\mathrm{b}}$ & $3.98 \pm 0.77^{\mathrm{c}}$ \\
\hline Se & 100 & $41 \pm 20^{\mathrm{a}}$ & $578 \pm 159^{b}$ & $227 \pm 82^{c}$ & $646 \pm 123^{b}$ \\
\hline $\mathbf{Z n}$ & 100 & $24 \pm 3^{\mathrm{a}, \mathrm{b}}$ & $25 \pm 2^{\mathrm{a}, \mathrm{c}}$ & $23 \pm 1^{b}$ & $27 \pm 2^{c}$ \\
\hline Se:Hg (molar) & & $207 \pm 90^{\mathrm{a}}$ & $636 \pm 153^{b}$ & $452 \pm 260^{\mathrm{b}, \mathrm{c}}$ & $427 \pm 115^{c}$ \\
\hline HCB & 100 & $0.9 \pm 0.5^{\mathrm{a}}$ & $3.3 \pm 0.8^{b}$ & $1.1 \pm 0.8^{b}$ & $0.2 \pm 0.1^{b, c}$ \\
\hline 4,4'-DDE* & 85 & $0.4 \pm 0.3(7)^{\mathrm{a}}$ & $2.5 \pm 0.8(9)^{\mathrm{b}}$ & $0.9 \pm 1.1(9)^{\mathrm{b}}$ & $1.3 \pm 0.6(10)^{\mathrm{c}}$ \\
\hline$\delta^{13} \mathrm{C}$ & & $-23.5 \pm 0.2^{\mathrm{a}}$ & $-22.7 \pm 0.2^{b}$ & $-20.2 \pm 0.4^{\mathrm{c}}$ & $-17.7 \pm 0.4^{\mathrm{d}}$ \\
\hline$\delta^{15} \mathbf{N}$ & & $11.4 \pm 0.5^{\mathrm{a}}$ & $10.3 \pm 0.7^{\mathrm{b}}$ & $10.5 \pm 0.7^{b}$ & $14.4 \pm 0.2^{\mathrm{c}}$ \\
\hline
\end{tabular}

* Number of individuals with concentrations > LOQ are in brackets. 
Table 2. AICc model ranking of blood concentrations of selected trace elements and POPs in chicks of four skua populations from the southern Indian Ocean ( $\mathrm{N}=41$ for all models). Abbreviations: AICc, Akaike's Information Criteria adjusted for small sample sizes; wi, AICc weights.

\begin{tabular}{lrrrrr} 
Models & $\boldsymbol{k}^{\mathbf{a}}$ & $\mathbf{A I C}_{\mathbf{c}}$ & $\boldsymbol{\Delta A I C}_{\mathbf{c}}^{\mathbf{b}}$ & $\boldsymbol{w}_{\boldsymbol{i}}^{\mathbf{c}}$ & Exp. var. $^{\mathbf{d}}$ \\
\hline $\mathbf{C u}$ & GLM, gamma distribution, inverse link function \\
Site & 4 & -63 & 0 & 0.71 & 0.81 \\
$\delta^{13} \mathrm{C}+$ Site & 5 & -61 & 2 & 0.20 & 0.81 \\
$\delta^{13} \mathrm{C}+$ Site $+\delta^{13} \mathrm{C}:$ Site & 8 & -59 & 4 & 0.09 & 0.83 \\
$\delta^{13} \mathrm{C}$ & 2 & -9 & 54 & 0 & 0.26 \\
Null & 1 & 2 & 65 & 0 & 0
\end{tabular}

Hg

$\delta^{13} \mathrm{C}+$ Site

Site

$\delta^{13} \mathrm{C}+$ Site $+\delta^{13} \mathrm{C}:$ Site

$\delta^{13} \mathrm{C}$

Null

Se

Site

$\delta^{13} \mathrm{C}+$ Site

$\delta^{13} \mathrm{C}+$ Site $+\delta^{13} \mathrm{C}$ :Site

$\delta^{13} \mathrm{C}$

Null

HCB

$\delta^{13} \mathrm{C}+$ Site $+\delta^{13} \mathrm{C}:$ Site

$\delta^{13} \mathrm{C}+$ Site

Site

$\delta^{13} \mathrm{C}$

Null

4,4'-DDE

$\delta^{13} \mathrm{C}+$ Site

Site

$\delta^{13} \mathrm{C}+$ Site $+\delta^{13} \mathrm{C}:$ Site

$\delta^{13} \mathrm{C}$

Null
GLM, log-transformed, gaussian distribution, identity link function

$\begin{array}{rrrrr}5 & 32 & 0 & 0.66 & 0.86 \\ 4 & 33 & 1.4 & 0.32 & 0.84 \\ 8 & 39 & 7.2 & 0.02 & 0.85 \\ 2 & 83 & 51 & 0 & 0.44 \\ 1 & 105 & 73 & 0 & 0\end{array}$

GLM, log-transformed, gaussian distribution, identity link function

$\begin{array}{rrrrr}4 & 40 & 0 & 0.73 & 0.91 \\ 5 & 43 & 2 & 0.25 & 0.91 \\ 8 & 47 & 7 & 0.02 & 0.91 \\ 2 & 121 & 80 & 0 & 0.33 \\ 1 & 136 & 95 & 0 & 0\end{array}$

GLM, gamma distribution, log link function

$\begin{array}{rrrrr}8 & 49 & 0 & 0.66 & 0.81 \\ 5 & 50 & 1 & 0.33 & 0.77 \\ 4 & 58 & 10 & 0.01 & 0.71 \\ 2 & 84 & 35 & 0 & 0.46 \\ 1 & 111 & 62 & 0 & 0\end{array}$

GLM, log-transformed, gaussian distribution, identity link function

$\begin{array}{rrrrr}5 & 142 & 0 & 0.91 & 0.45 \\ 4 & 147 & 5 & 0.08 & 0.36 \\ 8 & 151 & 9 & 0.01 & 0.42 \\ 2 & 161 & 18 & 0 & 0.05 \\ 1 & 161 & 19 & 0 & 0\end{array}$

\footnotetext{
${ }^{\mathrm{a}}$ Number of parameters

${ }^{\mathrm{b}}$ Scaled $\Delta \mathrm{AIC}_{\mathrm{c}} ; \Delta \mathrm{AIC}_{\mathrm{c}}=0.00$ is interpreted as the best fit to the data among the models

${ }^{\mathrm{c}}$ Weight of evidence interpreted as a proportion. Weights across all models sum to 1.00

${ }^{\mathrm{d}}$ Explained variation calculated from deviance, and adjusted depending on $k$ and $N$
} 
Fig 1. Biplot of individual scores extracted by principal component analyses (PCA) and element loadings on the two principal axes (PC1 and PC2), with standardised trace elements, POPs and $\delta^{13} \mathrm{C}$ values (as passive variable) in chick blood of four skua populations from the southern Indian Ocean. Abbreviations: KER, Kerguelen Islands; CRO, Crozet Islands; AMS, Amsterdam Island.

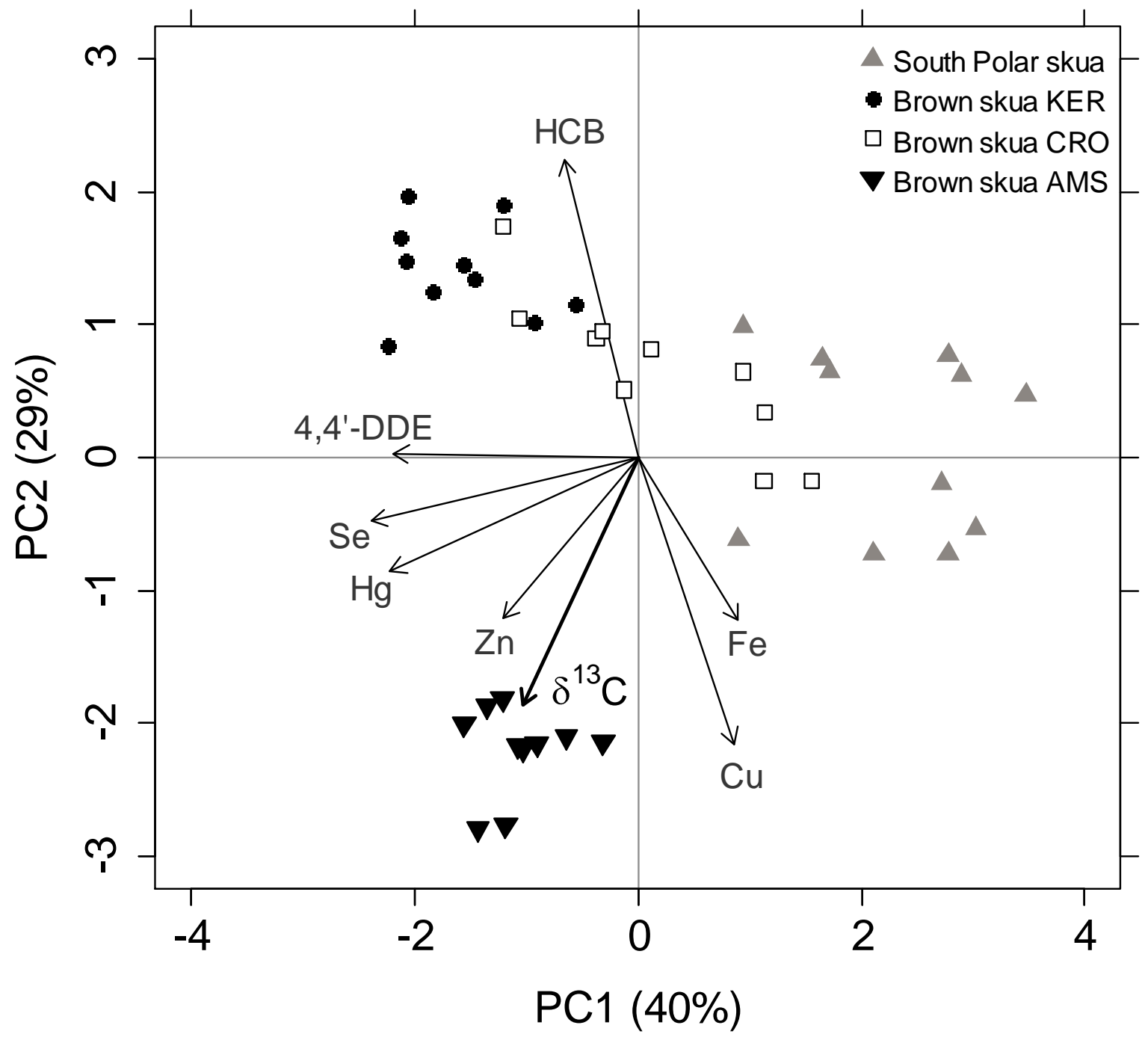


Fig 2. Boxplots of the concentrations of $\mathrm{Hg}$ and Se and relative contributions of $\mathrm{HCB}$ and 4,4'DDE to the $\Sigma_{18}$ POPs in chick blood of four skua populations from the southern Indian Ocean. Letters indicate significant inter-site differences in $\mathrm{Hg}$ and Se concentrations or HCB and 4,4'DDE relative contributions (multiple comparisons of means through Tukey contrasts of the best selected models for $\mathrm{Hg}$ and Se (Table 2), and of GLMs with a quasibinomial family for HCB and 4,4'-DDE relative contributions, $p<0.05$ ). Abbreviations: AL, Adélie Land; KER, Kerguelen Islands; CRO, Crozet Islands; AMS, Amsterdam Island.
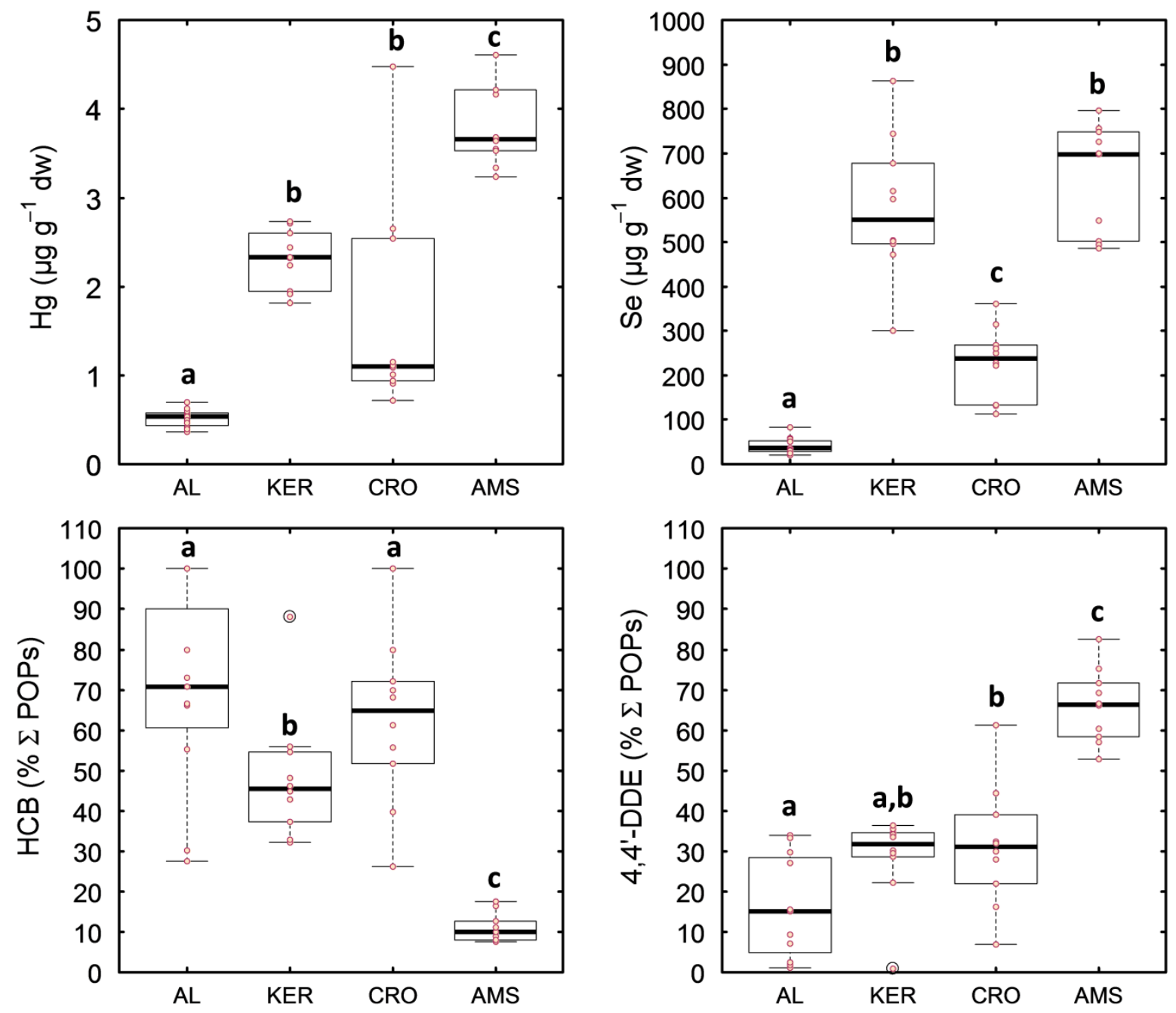